\title{
Assessment of Polymorphism of the VDR Gene and Serum Vitamin D Values in Gestational Diabetes Mellitus
}

\section{Avaliação do polimorfismo do gene VDR e valores séricos de vitamina $D$ no diabetes mellitus gestacional}

\author{
Thais Walverde Siqueira ${ }^{1}$ Edward Araujo Júnior ${ }^{1}$ Rosiane Mattar $^{1} \quad$ Silvia Daher ${ }^{1}$ \\ ${ }^{1}$ Escola Paulista de Medicina, Universidade Federal de São Paulo, \\ São Paulo, SP, Brazil \\ Address for correspondence Edward Araujo Júnior, PhD, Rua \\ Botucatu, 720, Vila Clementino, 04023-062, São Paulo, SP, Brazil \\ (e-mail: araujojred@terra.com.br).
}

Rev Bras Ginecol Obstet 2019;41:425-431.

\begin{abstract}
Keywords

- vitamin D

- genetic polymorphism

- gestational diabetes mellitus
\end{abstract}

Resumo
Objective To evaluate the relationship between vitamin D receptor (VDR) gene polymorphism (Fokl [rs10735810]) and serum vitamin D concentration in gestational diabetes mellitus (GDM).

Methods A prospective case-control study that recruited healthy pregnant women (control group) ( $n=78)$ and women with GDM (GDM group) $(n=79)$, with no other comorbidities. Peripheral blood samples were collected in the $3^{\text {rd }}$ trimester of gestation, and all of the pregnant women were followed-up until the end of the pregnancy and the postpartum period. Serum vitamin D concentrations were measured by high-performance liquid chromatography (HPLC). For genomic polymorphism analysis, the genomic DNA was extracted by the dodecyltrimethylammonium bromide/cetyltrimethylammonium bromide (DTAB/CTAB) method, and genotyping was performed by the polymerase chain reaction - restriction fragment length polymorphism (PCR-RFLP) technique, using the restriction enzyme Fokl. The Student-t, MannWhitney, chi-squared, and Fischer exact tests were used for the analysis of the results. Results There was no significant difference between the pregnant women in the control and GDM groups regarding serum vitamin D levels $(17.60 \pm 8.89 \mathrm{ng} / \mathrm{mL}$ versus $23.60 \pm 10.68 \mathrm{ng} / \mathrm{mL} ; p=0.1)$. Also, no significant difference was detected between the Fokl genotypic frequency when the 2 groups were compared with each other $(p=0.41)$.

Conclusion There was no association between the Fokl polymorphism and the development of GDM, nor was there any change in serum vitamin D levels in patients with GDM.

Objetivo Avaliar a relação entre o polimorfismo do gene receptor da vitamina $D$ (VDR) (Fokl [rs10735810]) e a concentração sérica de vitamina $\mathrm{D}$ no diabetes mellitus gestacional (DMG).

(1)Edward Araujo Júnior's ORCID is https://orcid.org/0000-00026145-2532.

received

March 21, 2019

accepted

June 4, 2019
DOI https://doi.org/

10.1055/s-0039-1693678. ISSN 0100-7203.
Copyright $(2019$ by Thieme Revinter

Publicações Ltda, Rio de Janeiro, Brazil
License terms

(c) (1) 


\author{
Palavras-chave \\ - vitamina D \\ - polimorfismo \\ genético \\ - diabetes mellitus \\ gestacional
}

\begin{abstract}
Métodos Estudo prospectivo tipo caso-controle que recrutou gestantes saudáveis (grupo controle) ( $n=78)$ e com DMG (grupo DMG) $(n=79)$, sem outras comorbidades. Foram coletadas amostras de sangue periférico no $3^{\circ}$ trimestre da gestação, e todas as gestantes foram acompanhadas até o final da gravidez e no pós-parto. As concentrações séricas de vitamina $D$ foram mensuradas por cromotografia líquida de alta eficiência (CLAE). Para análise do polimorfismo genético, o DNA genômico foi extraído pelo método de brometo de dodeciltrimetilamônio/brometo de cetiltrimetilamônio (DTAB/CTAB), e as genotipagens foram realizadas por técnica de reação de cadeia de polimerase - polimorfismo do comprimento do fragmento de restrição (PCRRFLP, na sigla em inglês), sendo empregada a enzima de restrição Fokl. Foram utilizados os testes t-Student, Mann-Whitney, qui-quadrado e exato de Fischer para a análise dos resultados.

Resultados Não houve diferença significativa entre as gestantes dos grupos controle e DMG quanto aos níveis séricos de vitamina $D(17,60 \pm 8,89 \mathrm{ng} / \mathrm{mL}$ versus $23,60 \pm 10,68 \mathrm{ng} / \mathrm{mL} ; p=0,1)$. Também não foi detectada diferença significativa entre a frequência genotípica de Fokl, quando comparados os 2 grupos entre si $(p=0,41)$.

Conclusão Não foi identificada associação do polimorfismo Fokl com o desenvolvimento de $D M G$, bem como não foi observada alteração nos níveis séricos de vitamina $D$ em pacientes com DMG.
\end{abstract}

\section{Introduction}

Gestational diabetes mellitus (GDM) is the most frequent metabolic disorder of pregnancy. It affects $\sim 3$ to $10 \%$ of pregnant women, depending on the population studied and on the diagnostic criteria adopted. ${ }^{1,2}$ Gestational diabetes mellitus is diagnosed when glucose intolerance, with consequent hyperglycemia, begins or is only identified during pregnancy, ${ }^{3}$ resulting from the inability of the pancreas to meet the increasing demand for insulin that usually occurs in the $2^{\text {nd }}$ trimester of pregnancy. ${ }^{3,4}$ It is known that GDM is a risk condition both for mother and child, with both immediate and long-term possible complications. ${ }^{5}$

The pathophysiology of GDM is complex and involves the participation of many factors and mechanisms. In addition to insulin resistance, other physiological processes, such as the development of inflammatory response, occur more exacerbatedly in cases of GDM. Thus, while in healthy gestations the inflammatory reaction is mild and transient, in GDM it seems to be more intense and persistent, characterized by hypersecretion of inflammatory cytokines. 6

In addition to being essential for calcium absorption and bone metabolism, vitamin $\mathrm{D}$ is recognized for its antiinflammatory effect. ${ }^{7}$ It also acts on the mechanism of glucose tolerance and insulin sensitivity. The mechanisms involved in these processes are not yet fully understood, but it is believed that insulin receptor expression increases, thus increasing the insulin response to glucose stimulation. This inverse relationship between vitamin $\mathrm{D}$ and the level of insulin resistance has been observed in different clinical conditions, among them diabetes mellitus (DM) II. ${ }^{8,9}$ The role of vitamin D in the pathophysiology of GDM has been investigated in recent years. Although there are controver- sies, several studies suggest that pregnant women with GDM present reduced levels of this vitamin. ${ }^{10,11}$

Most of the vitamin D receptor (VDR) gene polymorphisms are located in the 3' region of the gene, including the BsmI, ApaI and TaqI variants, ${ }^{12}$ while the Fokl polymorphism is located at the 5 ' end of the gene, near the promoter region. ${ }^{13}$ Some studies suggest the association of these polymorphisms with different clinical conditions, such as in the greater susceptibility to inflammatory ${ }^{14}$ and autoimmune ${ }^{15}$ diseases. To date, only one study has analyzed the relationship between genetic variants of the VDR gene and GDM, showing a positive association between the incidence of the disease and the VDR FokI polymorphism. ${ }^{16}$

The participation of vitamin $D$ in the pathophysiology of GDM has not yet been clarified. In addition, little is known about the relationship of polymorphisms related to the genes encoding this vitamin, as well as its receptor and the occurrence of the disease. The joint investigation of these parameters may bring new perspectives that help us to evaluate the risk of a pregnant woman developing GDM.

Therefore, the objective of the present study is to evaluate the relationship between VDR gene polymorphism (FokI) and the development of GDM. In addition, we intend to evaluate the correlation between the genotypes and their phenotypic expression, that is, the serum concentration of vitamin D.

\section{Methods}

\section{Participants}

A prospective case-control study was conducted at the Department of Obstetrics of the Universidade Federal de São Paulo 
(UNIFESP, in the Portuguese acronym), São Paulo, state of São Paulo, Brazil. The present study was approved by the Research Ethics Committee of the UNIFESP, and the women who consented to voluntary participation signed a Term of Consent. The inclusion criteria were: women of reproductive age $\geq 18$ years old, singleton gestation with live fetus, gestational age between 28 weeks and 1 day and 33 weeks and 6 days, pregestational body mass index $(\mathrm{BMI}) \geq 18.5 \mathrm{~kg} / \mathrm{m} 2$. The exclusion criteria were: pre-existing DM (I or II); fasting glycemia $\geq 126 \mathrm{mg} / \mathrm{dL}$ and/or random glycemia $\geq 200 \mathrm{mg} / \mathrm{dL}$ in the current gestation; carriers of pre-existing chronic diseases; carriers of acute infections; transplanted from solid organs; users of steroids, antibiotics, immunosuppressants, antihistamines or antiinflammatories; and drug users. For the diagnosis of GDM, the recommendation of the International Association of Diabetes and Pregnancy Study Groups (IADPSG) was used, that is, an altered cutoff point in the oral glucose tolerance test (OGTT) of $75 \mathrm{~g}$ (fasting $>92-125 \mathrm{mg} / \mathrm{dL}, 1$ hour $>180-199 \mathrm{mg} / \mathrm{dL}$, or 2 hours $>153-199 \mathrm{mg} / \mathrm{dL}) .{ }^{17}$ All of the participants recruited for the present study were followed-up until the end of the pregnancy. Pregnant women who abandoned prenatal care at the UNIFESP and those who were selected and subsequently presented any obstetric complications were excluded from the analysis. Two groups were set up, matched for race, gestational age and BMI, one with GDM and another as a control group. For the sample size calculation, the power of the test was considered to be $80 \%$, with an alpha error of $5 \%$ and a minimum difference of $10 \%$ between the groups for a minimum frequency of $11 \%$ of the risk allele in the control group. Based on these data, it was estimated that at least 50 participants should be included in each group.

\section{Blood Collection}

A total of $9 \mathrm{ml}$ of blood was collected by venous puncture, $5 \mathrm{~mL}$ in a dry tube and $4 \mathrm{~mL}$ in an EDTA tube (BD Diagnostics, Franklin Lakes, NJ, USA). The samples were transported in refrigerated thermal bags at a temperature between $2^{\circ} \mathrm{C}$ and $8^{\circ} \mathrm{C}$ to the Laboratory of Physiological and Experimental Obstetrics of the Department of Obstetrics of the UNIFESP and were processed up to 4 hours after collection. The DNA extraction sample (collected in the EDTA-containing tube) was centrifuged at 3,000 rpm for 10 minutes at $4^{\circ} \mathrm{C}$, and the buffy coat containing the polymorphonuclear cells was collected and stored at $-20^{\circ} \mathrm{C}$ for further processing. The samples collected in the dry tube were centrifuged after clot retraction at 3,500 rpm for 10 minutes at room temperature. The serum obtained was aliquoted and stored in a sterile and dry microtube at $-80^{\circ} \mathrm{C}$ for subsequent quantification of Vitamin D, and had a maximum shelf life of 3 months.

\section{Extraction of DNA}

The extraction of genomic DNA was performed by the dodecyltrimethylammonium bromide/ cetyltrimethylammonium bromide (DTAB/CTAB) technique, described by Gustincich et al. ${ }^{18} \mathrm{~A}$ total of $450 \mu \mathrm{l}$ of $12 \%$ DTAB solution was added to the buffy coat. After incubation at $67^{\circ} \mathrm{C}$ for 5 minutes, $900 \mu \mathrm{L}$ of chloroform was added. The sample was centrifuged for 2 minutes at $10,000 \mathrm{rpm}$, separating the material into 3 phases. The upper phase, with approximately $500 \mu \mathrm{L}$, was transferred to a tube with $900 \mu \mathrm{L}$ of distilled water and $100 \mu \mathrm{L}$ of $5 \%$ CTAB. After being stirred by inversion, the sample formed the precipitate of DNA-CTAB, again being centrifuged at $10,000 \mathrm{rpm}$ for 2 minutes, and the supernatant was discarded. The DNA precipitate was dissolved in $300 \mu \mathrm{L}$ of $1.2 \mathrm{M}$ $\mathrm{NaCl}$ solution and $750 \mu \mathrm{L}$ of $90 \%$ ethanol was added. With stirring by inversion, the DNA was precipitated and centrifuged at $13,000 \mathrm{rpm}$ for 2 minutes, the supernatant was discarded, and the DNA was washed with $70 \%$ ethanol, followed by another centrifugation. The supernatant was discarded and the DNA was dissolved in $120 \mu \mathrm{L}$ of distilled water. The final DNA concentration was adjusted to $100 \mathrm{ng} / \mu \mathrm{L}$, and was determined by spectrophotometer reading, with absorbance between 260 and $280 \mathrm{~nm}$ (UltroSpec III, Pharmacia Biothech, Uppsala, Sweden). The purity of the DNA was confirmed by the ratio $A_{260 n m} / A_{280 n m}$, considering acceptable values between 1.5 and 1.8 .

\section{Polymerase Chain Reaction}

Amplifications were performed under standard conditions for polymerase chain reaction (PCR) (Master Mix, Promega Corp., Madison, WI, USA), following the instructions of the manufacturer, using a Peltier Thermal Cycler MJ96G (Biocycle Co. Ltd., Hangzhou, China) with the conditions previously standardized for the primer of interest, according to the specific literature. The PCR-amplified products were analyzed by electrophoresis on 2\% agarose gel (Gibco BRL, Paisley, UK) for 45 minutes at $100 \mathrm{~V}$. Subsequently, they were submitted to the restriction fragment length polymorphism (RFLP) technique, which detects a genetic variation with the use of a restriction enzyme. The products obtained by digestion with restriction enzymes were analyzed by electrophoresis on 3\% agarose gel (Gibco BRL, Paisley, UK) for 45 minutes at $\sim 100 \mathrm{~V}$. To analyze the results, we used the E-BOX 300 UV capture system (Vilber Lourmat, Collégien, France).

\section{Genotyping of Polymorphisms}

The selected polymorphism is located in the VDR gene. The amplification of a segment of this region in which the polymorphism is contained was performed with the following cycling: initial denaturation performed with a cycle composed by denaturation at $94^{\circ} \mathrm{C}$ for 5 minutes, followed by 35 cycles composed by denaturation at $94^{\circ} \mathrm{C}$ for 30 seconds, annealing at $58^{\circ} \mathrm{C}$ for 45 seconds, and polymerization at $72^{\circ} \mathrm{C}$ for 55 seconds. The final extent was at $72^{\circ} \mathrm{C}$ for 10 minutes. For the analysis of this polymorphism, the sense and antisense primers used were: 5'-AGC TGG CCCTGG CAC TGA CTC TGC TCT-3' and 5'-ATG GAA ACA CCT TGC TTC TTCTCC CTC-3', respectively. The FokI restriction enzyme (New England Biolabs Inc., Ipswich, MA, USA) was added to this PCR product. ${ }^{19}$

\section{Evaluation of Serum Vitamin D Levels}

The most indicated technique for assessing vitamin $\mathrm{D}$ serum levels is high-performance liquid chromatography (HPLC). 20 The limit of vitamin detection was $1.4 \mu \mathrm{g} / \mathrm{L}$. The reference values established by the present study were defined as: ideal: 
between 20.0 and $70.0 \mathrm{ng} / \mathrm{mL}$; insufficient: between 10.0 and $20.0 \mathrm{ng} / \mathrm{mL}$; and deficient: $<10.0 \mathrm{ng} / \mathrm{mL}$.

\section{Statistical Analysis}

The Skewness and Kurtosis, Kolmogorov-Smirnov, and ShapiroWilk normality tests were performed to evaluate the distribution of quantitative variables. According to this evaluation, for the comparison of quantitative data, the Mann-Whitney test or the Student t-test for independent samples were applied. The Hardy-Weinberg equilibrium test was applied comparing the expected frequencies of each genotype with the observed values. The chi-squared or the Fisher exact test was used to compare qualitative variables. The significance level was set at $5 \%(p<0.05)$.

\section{Results}

First, 174 healthy pregnant women (control group) and 125 pregnant women with GDM (GDM group) were initially recruited. In the GDM group, 46 women were excluded, 1 due to gestational age outside the established interval, 1 due to pregestational $\mathrm{BMI} \geq 18.5 \mathrm{~kg} / \mathrm{m}^{2}, 3$ due to incomplete data, and 41 due to laboratory technical issues. In the control group, 96 women were excluded, 48 due to gestational age outside the established interval, 4 due to pregestational BMI $\geq 18.5 \mathrm{~kg} / \mathrm{m}^{2}$,
33 due to incomplete data, and 11 due to laboratory technical isssues. Thus, the study included 78 pregnant women and 79 pregnant women with GDM. - Table 1 shows the sociodemographic characteristics of the pregnant women evaluated for vitamin D concentration and genotyping of FokI polymorphism. We identified a difference in maternal age, which was significantly higher in the group of patients with GDM (33 \pm 5.7 versus. $30 \pm 6.7$ years old; $p=0.01$ ).

Serum vitamin D levels were evaluated in 52 pregnant women in the control group and in 41 patients with GDM. No significant difference was observed between the groups $(17.60 \pm 8.89 \mathrm{ng} / \mathrm{mL}$ versus. $23.60 \pm 10.68 \mathrm{ng} / \mathrm{mL} ; p=0.1$; for the control and GDM groups, respectively). We did not identify differences in serum vitamin D levels between pregnant controls and GDM patients, regardless of the degree of deficiency presented ( $\mathbf{- T a b l e ~} \mathbf{2}$ ).

The evaluation of the FokI polymorphism related to the VDR gene was performed in 76 pregnant women and in 72 women with GDM. No significant differences in genotype frequencies were identified separately $(p=0.41)$ or when we grouped to the $\mathrm{FF}+\mathrm{Ff}$ versus ff $(p=0.86)$, and neither for allele frequencies $(p=0.30$; odds ratio $[\mathrm{OR}]=0.75$; confidence interval $[\mathrm{CI}]=0.45-1.25)$ (-Table 3 ).

As the literature generally defines values $<20 \mathrm{ng} / \mathrm{mL}$ as vitamin D deficiency, we have redistributed our patients

Table 1 Main sociodemographic and clinical characteristics of the analyzed patients

\begin{tabular}{|c|c|c|c|c|}
\hline & & Control & GDM & \multirow[t]{2}{*}{ p-value } \\
\hline \multicolumn{2}{|l|}{ Variables } & $(n=78)$ & $(n=79)$ & \\
\hline \multirow[t]{3}{*}{ Age (years old)* } & Minimum-maximum & $18-43$ & $19-44$ & \multirow[t]{3}{*}{$0.01^{* *}$} \\
\hline & Mean & 30 & 33 & \\
\hline & Standard deviation & 6.705 & 5.735 & \\
\hline \multirow[t]{3}{*}{ Gestational age at collection (weeks)* } & Minimum-maximum & $256 / 7-336 / 7$ & $211 / 7-381 / 7$ & \multirow[t]{3}{*}{0.07} \\
\hline & Mean & $301 / 7$ & $306 / 7$ & \\
\hline & Standard deviation & 1.872 & 2.942 & \\
\hline \multirow[t]{3}{*}{ Pregestational BMI $\left(\mathrm{Kg} / \mathrm{m}^{2}\right)^{*}$} & Minimum-maximum & $18.50-38.57$ & $18.80-38.20$ & \multirow[t]{3}{*}{0.35} \\
\hline & Mean & 26.70 & 25.80 & \\
\hline & Standard deviation & 4.448 & 4.446 & \\
\hline \multirow[t]{3}{*}{ Ethnicity $^{\dagger}$} & White & $29(37.18 \%)$ & $32(40.51 \%)$ & \multirow[t]{3}{*}{0.78} \\
\hline & Brown-skinned & $47(60.26 \%)$ & $46(58.23 \%)$ & \\
\hline & Black & $02(2.56 \%)$ & $01(1.26 \%)$ & \\
\hline \multirow[t]{3}{*}{ Parity $^{\dagger}$} & 0 & $24(30.77 \%)$ & 18 (22.78\%) & \multirow[t]{3}{*}{0.50} \\
\hline & 1 & $30(38.46 \%)$ & 32 (40.51\%) & \\
\hline & +2 & $24(30.77 \%)$ & 29 (36.71\%) & \\
\hline \multirow[t]{2}{*}{ Smoke } & Yes & $8(10.26 \%)$ & $7(8.86 \%)$ & \multirow[t]{2}{*}{0.79} \\
\hline & No & 70 (89.74\%) & 72 (91.14\%) & \\
\hline \multirow{2}{*}{ 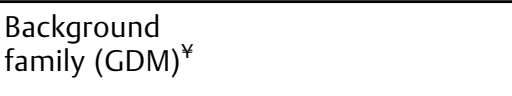 } & Yes & 14 (17.95\%) & 21 (26.58\%) & \multirow[t]{2}{*}{0.25} \\
\hline & No & 64 (82.05\%) & 58 (73.42\%) & \\
\hline
\end{tabular}

Abbreviations: BMI, body mass index; GDM, gestational diabetes mellitus.

${ }^{*}$ Student t-test; ${ }^{\dagger}$ Chi-squared test; ${ }^{*}$ Fisher exact test ${ }^{* *} p<0.05$. 
Table 2 Serum levels of Vitamin D in healthy patients (controls), and in patients with gestational diabetes mellitus

\begin{tabular}{|c|c|c|c|c|}
\hline \multirow{2}{*}{\multicolumn{2}{|c|}{$\begin{array}{l}\text { Variables } \\
\text { Serum levels of vitamin D }\end{array}$}} & \multirow{3}{*}{$\begin{array}{l}\text { Control } \\
(n=52) \\
7\end{array}$} & \multirow{3}{*}{$\begin{array}{l}\text { GDM } \\
(n=41) \\
3\end{array}$} & \multirow[t]{2}{*}{ p-value } \\
\hline & & & & \\
\hline \multirow[t]{4}{*}{$<10 \mathrm{ng} / \mathrm{mL}^{£}$} & $n$ & & & \multirow[t]{4}{*}{1.00} \\
\hline & Minimum-maximum & $4.400-9.100$ & $6.700-7.900$ & \\
\hline & Median & 7.50 & 7.30 & \\
\hline & Standard deviation & 1.604 & 0.6000 & \\
\hline \multirow[t]{4}{*}{$10-20 \mathrm{ng} / \mathrm{mL}^{\mathrm{E}}$} & $n$ & 24 & 14 & \multirow[t]{4}{*}{0.32} \\
\hline & Minimum-maximum & $10.40-19.70$ & $10.00-19.20$ & \\
\hline & Median & 15.70 & 14.40 & \\
\hline & Standard deviation & 2.960 & 2.614 & \\
\hline \multirow[t]{4}{*}{$20.1-29.9 \mathrm{ng} / \mathrm{mL}^{\mathrm{f}}$} & $n$ & 11 & 12 & \multirow[t]{4}{*}{0.78} \\
\hline & Minimum-maximum & $21.10-29.80$ & $20.20-29.60$ & \\
\hline & Median & 23.50 & 24.85 & \\
\hline & Standard deviation & 3.181 & 2.833 & \\
\hline \multirow[t]{4}{*}{$\geq 30 \mathrm{ng} / \mathrm{mL}^{\mathrm{f}}$} & $n$ & 10 & 12 & \multirow[t]{4}{*}{0.06} \\
\hline & Minimum-maximum & $30.50-36.80$ & $31.40-48.10$ & \\
\hline & Median & 32.15 & 35.05 & \\
\hline & Standard deviation & 2.343 & 5.454 & \\
\hline
\end{tabular}

Abbreviation: GDM, gestational diabetes mellitus.

${ }^{\mathrm{E}}$ Mann-Whitney test.

Table 3 Genotypic (FG) and allelic (FA) frequencies of Fokl polymorphism in control pregnant women with and in women with gestational diabetes mellitus

\begin{tabular}{|l|l|l|l|l|}
\hline \multicolumn{2}{|c|}{} & Control & GDM & p-value \\
\hline \multirow{5}{*}{ FG } & FF & $37(48.68 \%)$ & $39(54.17 \%)$ & \multirow{2}{*}{$0.39^{\dagger}$} \\
\cline { 2 - 4 } & $\mathrm{Ff}$ & $30(39.47 \%)$ & $29(40.28 \%)$ & \\
\cline { 2 - 4 } & $\mathrm{Ff}$ & $9(11.85 \%)$ & $4(5.55 \%)$ & \\
\cline { 2 - 4 } & $\mathrm{FF}+\mathrm{Ff}$ & $67(88.16 \%)$ & $68(94.45 \%)$ & $0.25^{*}$ \\
\cline { 2 - 4 } & Total & 76 & 72 & \\
\cline { 2 - 4 } & $\mathrm{EWH}$ & $p=0.45$ & $p=0.64$ & \\
\hline \multirow{3}{*}{ FA } & $\mathrm{F}$ & 104 & 107 & \multirow{2}{*}{$0.30^{*}$} \\
\cline { 2 - 4 } & $\mathrm{F}$ & 48 & 37 & \\
\hline
\end{tabular}

Abbreviation: GDM, gestational diabetes mellitus.

${ }^{\dagger}$ Chi-squared test; ${ }^{*}$ Fisher exact test.

according to this parameter and reanalyzed the results. Significant differences were not identified for genotypic frequencies analyzed separately $(p=0.47)$, or when we grouped for the FF + Ff standard versus ff $(p=0.67)$, as observed in - Table 4.

\section{Discussion}

Our hypothesis was that pregnant women with GDM had lower levels of vitamin $D$ than controls, and that this imbalance was possibly related to genetic predisposition. However, we
Table 4 Ratio of genotype versus. phenotype (gestational diabetes mellitus + control) according to reference values in the literature

\begin{tabular}{|c|c|c|c|}
\hline & $<20 \mathrm{ng} / \mathrm{mL}$ & $\geq 20 \mathrm{ng} / \mathrm{mL}$ & p-value \\
\hline FF & $24(52.17 \%)$ & 21 (55.26\%) & \multirow[t]{3}{*}{$0.47^{\dagger}$} \\
\hline $\mathrm{Ff}$ & 17 (36.96\%) & 15 (39.47\%) & \\
\hline $\mathrm{Ff}$ & 05 (10.87\%) & 02 (5.26\%) & \\
\hline$F F+F f$ & 41 (89.13\%) & 36 (94.73\%) & $0.67^{*}$ \\
\hline Total & 46 & 38 & \\
\hline
\end{tabular}

${ }^{\dagger}$ Chi-squared test; ${ }^{*}$ Fisher exact test.

did not observe alterations in serum vitamin $\mathrm{D}$ levels in patients with GDM when compared with controls. We also did not identify any association between genetic polymorphism of the VDR gene and the occurrence of GDM, nor a correlation between genotype and phenotype.

Recognized for its anti-inflammatory effect and for its role in glucose metabolism, vitamin $\mathrm{D}$ has been implicated in the pathophysiology of different clinical conditions, such as obesity and DM II. ${ }^{20,21}$ Vitamin D deficiency appears to have a dosedependent effect on glucose homeostasis, on insulin secretion, and on insulin resistance. Although controversial, most studies suggest that patients with DM II have deficiency of this vitamin. $^{22,23}$

Regarding gestation, a recent systematic review showed the importance of this vitamin for gestational success, and its deficiency is associated with different obstetric complications. ${ }^{24}$ 
Reduced levels of vitamin D appear to compromise the physiological adaptation process of the pregnant woman, increasing the degree of inflammation and insulin resistance, preventing the adequate development of the pregnancy. Thus, an association between low vitamin D levels and increased risk of severe preeclampsia and of preterm delivery has been reported. ${ }^{25,26}$ In an obese African-American population, a positive relationship between vitamin D deficiency and GDM was significant only in groups of pregnant smokers. ${ }^{11}$

Due to the limitations of the population attending our service, environmental and ethnic issues were not considered as exclusion or inclusion parameters. Our study group was relatively homogeneous regarding the sociodemographic status of the participants.

The role of vitamin D in the pathophysiology of GDM is controversial. ${ }^{10}$ These controversies are related to several factors, such as the heterogeneity of the studies performed regarding the gestational age at the time of sample collection, the ethnic groups evaluated, differences in the degree of sun exposure (season, geographic region, occupation), among others. ${ }^{27-29}$ Age also interferes in the levels of this vitamin due to hormonal changes in women, and because age influences the degree of sun exposure, according to several authors. ${ }^{30-32}$

In our study, we have adopted levels of vitamin $\mathrm{D} \geq 20$ $\mathrm{ng} / \mathrm{mL}$ as adequate or sufficient, 10 to $20 \mathrm{ng} / \mathrm{mL}$ as insufficient, and $<10 \mathrm{ng} / \mathrm{mL}$ as deficient. To date, there are no reference values for serum vitamin $\mathrm{D}$ throughout gestation. Considering the cutoff points we have set for the present study, about half of the cases included had some degree of vitamin D deficiency, and the controls had lower levels than the GDM group. We believe that limitations in relation to the degree of sun exposure, to the nutritional status or race could have influenced our results.

In the present study, we have evaluated serum samples collected in the $2^{\text {nd }}$ and $3^{\text {rd }}$ trimesters of pregnancy in order to confirm the role of vitamin $\mathrm{D}$ in the pathophysiology of GDM. However, most of the studies analyze the predictive value of this dosage for the detection of the patient at risk of GDM. ${ }^{11}$ Therefore, the serum levels in patients $<16$ weeks of gestation are analyzed and, later, this data is confronted with the development of the disease. They are different evaluations that can justify the divergences found, even in relation to the prediction. ${ }^{33,34}$ It is also worth noting that, to date, there is no evidence that vitamin D supplementation improves the obstetric prognosis.

Regarding the genetic study, we did not identify an association between the FokI VDR polymorphism (rs10735810) and the occurrence of GDM. The only study to date shows a positive association between GDM and the FokI polymorphism, but in the Iranian population. In this study, the authors showed that the frequencies of this polymorphism differ between ethnic groups, suggesting that the results obtained in a given population cannot be generalized. ${ }^{16}$ Even the relationship between this polymorphism and DM II is still controversial, probably because of the differences between the sociodemographic, and even the clinical characteristics that exist in the studied populations.
In the present study, no correlation between genotype and phenotype was identified. These relationships are generally observed under restricted technical conditions and in samples with specific characteristics. As limitations, we point out the relatively small number of cases, due to the difficulties faced in selecting participants who fulfilled all the established criteria. As a positive point, it is the first study that evaluated these parameters in a Brazilian pregnant population. The present study included a relatively small number of cases, due to the difficulties faced in selecting participants who met all of the established criteria. The results are preliminary and will need to be validated in future prospective studies with larger samples. Despite these limitations, the present study was a pioneer in the assessment of these parameters in a Brazilian pregnant population.

\section{Conclusion}

In summary, there was no change in serum vitamin $\mathrm{D}$ levels in patients with GDM, nor was there an association between the FokI polymorphism and the development of GDM. In addition, no relationship was observed between phenotype, serum vitamin D level, and the genotype, genetic variant related to FokI.

\section{Contributors}

Siqueira T. W., Araujo Júnior E., Mattar R., and Daher S. contributed with the project and the interpretation of data, the writing of the article, the critical review of the intellectual content, and with the final approval of the version to be published.

\section{Conflicts of Interests}

The authors have no conflicts of interests to declare.

\section{References}

1 Bener A, Saleh NM, Al-Hamaq A. Prevalence of gestational diabetes and associated maternal and neonatal complications in a fastdeveloping community: global comparisons. Int J Womens Health 2011;3:367-373. Doi: 10.2147/IJWH.S26094

2 Nair AV, Hocher B, Verkaart S, et al. Loss of insulin-induced activation of TRPM6 magnesium channels results in impaired glucose tolerance during pregnancy. Proc Natl Acad Sci U S A 2012;109(28):11324-11329. Doi: 10.1073/pnas.1113811109

3 Basso NA, Costa RAA, Magalhães CG, Rudge MVC, Calderon IMP. [Insulinotherapy, maternal glycemic control and perinatal prognosis - difference between clinical and gestational diabetes]. Rev Bras Ginecol Obstet 2007;29(Suppl 5):253-259. Doi: 10.1590/ S0100-72032007000500006

4 Buchanan TA, Xiang A, Kjos SL, Watanabe R. What is gestational diabetes? Diabetes Care 2007;30(Suppl 2):S105-S111. Doi: $10.2337 / \mathrm{dc} 07-\mathrm{s} 201$

5 Yadav AD, Chang YH, Aqel BA, et al. New onset diabetes mellitus in living donor versus deceased donor liver transplant recipients: analysis of the UNOS/OPTN Database. J Transplant 2013;2013: 269096. Doi: $10.1155 / 2013 / 269096$

6 Cline J. Calcium and vitamin d metabolism, deficiency, and excess. Top Companion Anim Med 2012;27(04):159-164. Doi: 10.1053/j. tcam.2012.09.004 
7 Pittas AG, Lau J, Hu FB, Dawson-Hughes B. The role of vitamin D and calcium in type 2 diabetes. A systematic review and metaanalysis. J Clin Endocrinol Metab 2007;92(06):2017-2029. Doi: 10.1210/jc.2007-0298

8 Cangoz S, Chang YY, Chempakaseril SJ, et al. Vitamin D and type 2 diabetes mellitus. J Clin Pharm Ther 2013;38(02):81-84. Doi: $10.1111 /$ jcpt.12026

9 Palomer X, González-Clemente JM, Blanco-Vaca F, Mauricio D. Role of vitamin $\mathrm{D}$ in the pathogenesis of type 2 diabetes mellitus. Diabetes Obes Metab 2008;10(03):185-197. Doi: 10.1111/j.14631326.2007.00710.x

10 Perez-Ferre N, Torrejon MJ, Fuentes M, et al. Association of low serum 25-hydroxyvitamin D levels in pregnancy with glucose homeostasis and obstetric and newborn outcomes. Endocr Pract 2012;18(05):676-684. Doi: 10.4158/EP12025.OR

11 Joergensen JS, Lamont RF, Torloni MR. Vitamin D and gestational diabetes: an update. Curr Opin Clin Nutr Metab Care 2014;17(04): 360-367. Doi: 10.1097/MCO.0000000000000064

12 Panierakis C, Goulielmos G, Mamoulakis D, Petraki E, Papavasiliou E, Galanakis E. Vitamin D receptor gene polymorphisms and susceptibility to type 1 diabetes in Crete, Greece. Clin Immunol 2009;133(02):276-281. Doi: 10.1016/j.clim.2009.08. 004

13 Uitterlinden AG, Fang Y, Van Meurs JB, Pols HA, Van Leeuwen JP. Genetics and biology of vitamin D receptor polymorphisms. Gene 2004;338(02):143-156. Doi: 10.1016/j.gene.2004.05.014

14 Wöbke TK, Sorg BL, Steinhilber D. Vitamin D in inflammatory diseases. Front Physiol 2014;5:244. Doi: 10.3389/fphys.2014.00244

15 Székely JI, Pataki Á. Effects of vitamin D on immune disorders with special regard to asthma, COPD and autoimmune diseases: a short review. Expert Rev Respir Med 2012;6(06):683-704. Doi: 10.1586/ers. 12.57

16 Aslani S, Hossein-Nezhad A, Mirzaei K, Maghbooli Z, Afshar AN, Karimi F. VDR FokI polymorphism and its potential role in the pathogenesis of gestational diabetes mellitus and its complications. Gynecol Endocrinol 2011;27(12):1055-1060. Doi: 10.3109/ 09513590.2011 .569786

17 Metzger BE, Gabbe SG, Persson B, et al; International Association of Diabetes \& Pregnancy Study Groups (IADPSG) Consensus Panel Writing Group and the Hyperglycemia \& Adverse Pregnancy Outcome (HAPO) Study Steering Committee. The diagnosis of gestational diabetes mellitus: new paradigms or status quo? J Matern Fetal Neonatal Med 2012;25(12):2564-2569. Doi: 10.3109/14767 058.2012.718002

18 Gustincich S, Manfioletti G, Del Sal G, Schneider C, Carninci P. A fast method for high-quality genomic DNA extraction from whole human blood. Biotechniques 1991;11(03):298-300, 302

19 Neyestani TR, Djazayery A, Shab-Bidar S, et al. Vitamin D Receptor Fok-I polymorphism modulates diabetic host response to vitamin D intake: need for a nutrigenetic approach. Diabetes Care 2013;36 (03):550-556. Doi: 10.2337/dc12-0919
20 Holick MF. Vitamin D status: measurement, interpretation, and clinical application. Ann Epidemiol 2009;19(02):73-78. Doi: 10.1016/j.annepidem.2007.12.001

21 Bid HK, Konwar R, Aggarwal CG, et al. Vitamin D receptor (FokI, BsmI and TaqI) gene polymorphisms and type 2 diabetes mellitus: a North Indian study. Indian J Med Sci 2009;63(05):187-194. Doi: 10.4103/0019-5359.53164

22 Bachali S, Dasu K, Ramalingam K, Naidu JN. Vitamin d deficiency and insulin resistance in normal and type 2 diabetes subjects. Indian J Clin Biochem 2013;28(01):74-78. Doi: 10.1007/s12291-012-0239-2

23 Chaudhary S, Thukral A, Tiwari S, Pratyush DD, Singh SK. Vitamin D status of patients with type 2 diabetes and sputum positive pulmonary tuberculosis. Indian J Endocrinol Metab 2013;17 (Suppl 3):S670-S673. Doi: 10.4103/2230-8210.123564

24 Wei SQ, Qi HP, Luo ZC, Fraser WD. Maternal vitamin D status and adverse pregnancy outcomes: a systematic review and metaanalysis. J Matern Fetal Neonatal Med 2013;26(09):889-899. Doi: 10.3109/14767058.2013.765849

25 Bodnar LM, Simhan HN, Catov JM, et al. Maternal vitamin D status and the risk of mild and severe preeclampsia. Epidemiology 2014; 25(02):207-214. Doi: 10.1097/EDE.0000000000000039

26 Bodnar LM, Krohn MA, Simhan HN. Maternal vitamin D deficiency is associated with bacterial vaginosis in the first trimester of pregnancy. J Nutr 2009;139(06):1157-1161. Doi: 10.3945/jn.108.103168

27 Kaushal M, Magon N. Vitamin D in pregnancy: A metabolic outlook. Indian J Endocrinol Metab 2013;17(01):76-82. Doi: 10.4103/2230-8210.107862

28 Maeda SS, Hayashi L, Pereira RL, Lazaretti-Castro M. Influência dos aspectos ocupacionais e da sazonalidade nas concentrações de 25-Hidroxivitamina $\mathrm{D}$ em população jovem saudável da cidade de São Paulo. Arq Bras Endocrinol Metabol 2004;48:S501

29 Soheilykhah S, Mojibian M, Rashidi M, Rahimi-Saghand S, Jafari F. Maternal vitamin D status in gestational diabetes mellitus. Nutr Clin Pract 2010;25(05):524-527. Doi: 10.1177/08845336 10379851

30 Webb AR, Kline L, Holick MF. Influence of season and latitude on the cutaneous synthesis of vitamin D3: exposure to winter sunlight in Boston and Edmonton will not promote vitamin D3 synthesis in human skin. J Clin Endocrinol Metab 1988;67(02):373-378. Doi: 10.1210/jcem-67-2-373

31 van der Wielen RP, Löwik MR, van den Berg H, et al. Serum vitamin D concentrations among elderly people in Europe. Lancet 1995; 346(8969):207-210. Doi: 10.5555/uri:pii:S0140673695912665

32 Jacques PF, Felson DT, Tucker KL, et al. Plasma 25-hydroxyvitamin $D$ and its determinants in an elderly population sample. Am J Clin Nutr 1997;66(04):929-936. Doi: 10.1093/ajcn/66.4.929

33 Martineau AR, Khan K. Maternal vitamin D insufficiency is associated with adverse pregnancy and neonatal outcomes. Evid Based Med 2014;19(01):e4. Doi: 10.1136/eb-2013-101368

34 Lewis S, Lucas RM, Halliday J, Ponsonby AL. Vitamin D deficiency and pregnancy: from preconception to birth. Mol Nutr Food Res 2010;54(08):1092-1102. Doi: 10.1002/mnfr.201000044 